\section{Ignimbrite veneer deposits or pyroclastic surge deposits?}

RECENTLY, Walker and others ${ }^{1}$ applied the concept of aspect ratio ${ }^{2,3}$ to ignimbrites and we accept this as valid reasoning. An outstanding feature of the lowaspect ratio Taupo and Rabual ignimbrites (deposits of pumiceous pyroclastic flows) they describe is a landscape-mantling deposit (ignimbrite veneer deposit) which can be traced into a more conventional topography-infilling ignimbrite (valley-ponded ignimbrite). According to Walker and others ${ }^{1}$, recognition of these new features requires that a reappraisal be made of the emplacement mechanisms and new diagnostic criteria be drawn up for recognizing pyroclastic types. We, however, question this statement.

In the lesser Antilles, several pyroclastic flow deposits that fill valleys have been traced into finer-grained, stratified and cross-stratified deposits which mantle the interfluves between valleys. These deposits are interpreted by us as the deposits of ash-cloud pyroclastic surges. Ash-cloud surges are outwardly expanding dilute pyroclastic flows derived from an underflow or pyroclastic flow sensu stricto $^{4-6}$. The flow and surge have fundamentally different transport mechanisms. Pyroclastic flows are highconcentration flows that move by laminar and/or plug flow ${ }^{7,8}$. Deposits are typically massive, poorly sorted and topographically controlled. Surges are flows that are turbulent and deposit beds with internal stratification and cross-stratification ${ }^{4-6}$. Surges are not topographically controlled and deposits can mantle landscape adhering to relatively steep slopes.

Walker and others ${ }^{1}$ imply that the ignimbrite veneer deposit is the deposit of a high-concentration flow. The veneer is regarded by them as a 'tail deposit' left in the wake of the pyroclastic flow. From their description we contend that this tail deposit is the deposit of an ash-cloud surge derived from the main flow and is its lateral equivalent.

\section{R. V. FISHER}

Department of Geological Sciences, University of California at Santa Barbara, Santa Barbara, California 93106

\section{A. L. SMITH J. V. WRIGHT M. J. ROOBOL}

Department of Geology,

University of Puerto Rico,

Mayaguez, Puerto Rico 00708

\footnotetext{
. Walker, G. P. L., Heming, R. F. \& Wilson, C. J. N. Nature 283, 286 (1980).

2. Walker, G. P. L. Phil. Trans. R. Soc. A274, 107 (1973).

3. Hulme, G. Geophys. J. R. astr. Soc. 39, 361 (1974).

4. Fisher, R. V. J. Volcanol. geotherm. Res. 6, 305 (1979)

5. Fisher, R. V., Smith, A. L. \& Roobol, M. J. Geology (in the Fisher, $R$.
press).

6. Wright, J. V., Smith, A. L. \& Self, S. J. Volcanol. geotherm Res. (in the press).

7. Sparks, R. S. J. Sedimentology 23, 147 (1976).

8. Wright, J. V. thesis, Univ. London (1979).
}

WALKER ET AL. REPLY-We accept without reservation the relationships described by Fisher and others from the Lesser Antilles. We have long believed in the concept that pyroclastic flows sensu stricto and pyroclastic surges have fundamentally different transport mechanisms. What is in question, however, is not the basic concept but the origin of certain rocks occurring specifically at Taupo and Rabaul Volcanoes: the rocks which we have called ignimbrite veneer deposits (IVDs).

We considered very carefully the possibility that our IVDs might have been emplaced in the way that Fisher and others propose, but rejected it for the five reasons outlined below.

First, apart from having a generally smaller content of coarse pumice, the IVD is identical in its grain-size characteristics with the valley pond ignimbrite, and has identical pumice density and crystal and lithic sizes and contents. There is no laboratory test that we can apply to distinguish between the two. Moreover, the IVD is visibly in lateral continuity with, and passes gradually into, the valley pond ignimbrite.

Second, the sheer scale of the IVD at Taupo seems to us to negate the idea that it could be the deposit of a surge generated at the vent; we think it highly unlikely that any pyroclastic surge is capable of moving radially outwards against air resistance, and of remaining highly turbulent long enough, to encompass a nearly-circular area measuring more than $160 \mathrm{~km}$ across, or of carrying $>10^{13} \mathrm{~kg}$ of poorly sorted pyroclastic material held entrained in its gas. We note that all known far-reaching pyroclastic surges have originated on steep and high cones, and the most farreaching one (Bezymianny $1956^{1}$ ) was strongly directional, yet it travelled no further than $29 \mathrm{~km}$. The Taupo IVD is not directional, and there is no evidence that it originated on a steep or high volcanic cone.

Third, the scale again seems to us to preclude the possibility that the IVD was generated by a whole succession of pyroclastic surges jetting forwards from the advancing ash-flow, which is presumably the mechanism that Fisher and others envisage. We do not deny that such jetting may and probably does occur, but we would expect the surges to carry much less particulate material than the parent body. This relationship certainly holds at Mt Pelée (Martinique) where one of us (G.P.L.W.) has worked. At Taupo, however, the IVD constitutes about $50 \%$ of the total ignimbrite volume, and at Rabaul as much as $75 \%$. We note that the higher the proportion of 'surge-deposited' material, the more closely in effect does the 'jetting surge' concept converge on the single 'vent-generated-surge' one.

In the 'jetting surge' model we would, moreover, expect some kind of close relationship to exist between the thickness and lateral spread of a surge deposit and the position of adjacent valley ponds, but we find no such relationship. There are many places where a normal thickness of IVD is found several kilometres laterally from, and often several hundred metres higher than, the nearest substantial valley pond.

Fourth, at Taupo we have found ponded ignimbrite in many valleys where, to reach them, the parent flow must have crossed ridges or passes standing hundreds of metres higher than the present vent position. The most extreme ignimbrite pond we know is $2-3 \mathrm{~m}$ deep, contains pumice fragments up to $30 \mathrm{~cm}$ in diameter and occurs high on Tongariro Mountain, $45 \mathrm{~km}$ laterally from and $1,500 \mathrm{~m}$ higher than its source vent. We know of no way that this valley pond could have formed other than by the passage of a high-concentration pyroclastic flow right across the mountain.

Fifth, undoubted pyroclastic surge deposits differ notably in grain size and constitution from ignimbrite. The deposits of a more or less cold (and often wet) base surge are generally well stratified, and the beds (which have a thickness commonly measured in millimetres or centimetres) associated in the same bedding set commonly vary in median diameter over a range of 5 phi units or more. In contrast, in the IVD the layers (apart from certain pumice lenses) vary typically over a range of less than $1 \mathrm{phi}$, and the presence of carbonized vegetation indicates that they were hot. The deposits of a hot pyroclastic surge (such as the dilute component of a peléean nuée ardente) are totally different in character from ignimbrite, typically being very strongly enriched in the denser constituents (lithic fragments, crystals) and strongly depleted in fine dust.

We are convinced from these relationships that our IVD is indeed the deposit from a high-concentration flow, a pyroclastic flow sensu stricto, and cannot have been produced by any surge mechanism involving a dilute 'ash cloud'. Clearly, emplacements of both the Taupo and Rabaul ignimbrites were quite exceptionally violent events, far beyond the experience of civilized man, and we believe that there is a limit to how far their products can be interpreted from the study of such relatively minor eruptions as the 1902 nuée ardente of Mt Pelée.

\section{G. P. L. WALKER R. F. HEMING}

Geology Department,

University of Auckland,

New Zealand

\section{J. N. WII.SON}

Geology Department,

Imperial College,

London SW7 $2 A Z, U K$

1. Gorshkov, G. S. Bull. Volcanol. 20, 77 (1959). 